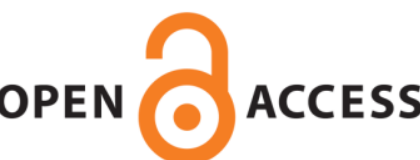

OPEN ACCESS

UWS Academic Portal

\title{
On the relationship between Catholicism and Marxism
}

James, Kieran; Leung, Jenny Kwai-Sim

Published in:

International Journal of Critical Accounting

DOI:

10.1504/IJCA.2018.10013413

Published: 28/05/2018

Document Version

Peer reviewed version

Link to publication on the UWS Academic Portal

Citation for published version (APA):

James, K., \& Leung, J. K-S. (2018). On the relationship between Catholicism and Marxism. International Journal of Critical Accounting, 10(2), 169-191. https://doi.org/10.1504/IJCA.2018.10013413

\section{General rights}

Copyright and moral rights for the publications made accessible in the UWS Academic Portal are retained by the authors and/or other copyright owners and it is a condition of accessing publications that users recognise and abide by the legal requirements associated with these rights.

Take down policy

If you believe that this document breaches copyright please contact pure@uws.ac.uk providing details, and we will remove access to the work immediately and investigate your claim. 


\title{
On the relationship between Catholicism and Marxism
}

By

\author{
Kieran James* \\ University of the West of Scotland, Scotland and University of Fiji, Fiji \\ Islands \\ Postal address: School of Business and Enterprise, \\ University of the West of Scotland, \\ Paisley campus, \\ Paisley PA1 2BE, \\ Renfrewshire, \\ Scotland \\ Kieran.James99@yahoo.co.uk and Kieran.James@uws.ac.uk
}

and

\author{
Jenny Kwai-Sim Leung \\ Charles Sturt University, Australia \\ Postal address: Locked Bag 588, \\ Wagga Wagga NSW 2678, \\ Australia \\ Leung_kwai@yahoo.co.uk
}

*Corresponding Author. Address for Correspondence: Dr Kieran James, School of Business and Enterprise, University of the West of Scotland, Paisley campus, Paisley PA1 2BE, Renfrewshire, Scotland, tel: +44 (0)141 848 3350, e-mail: Kieran.James@uws.ac.uk and Kieran.James99@yahoo.co.uk,

Acknowledgements: We would like to thank the two anonymous reviewers for the present journal for their helpful and insightful comments. 


\section{Author bios:}

Dr Kieran James is a Senior Lecturer in Accounting at the University of the West of Scotland, Paisley PA1 2BE, Renfrewshire, Scotland. He was formerly Accounting Professor at University of Fiji from 2013-15. He has published scholarly articles in the following journals: Critical Perspectives on Accounting, International Journal of Critical Accounting, International Journal of Social Economics, International Journal of Sport Management and Marketing, Korean Journal of Industrial Relations, Musicology Australia, Punk \& PostPunk, and Sporting Traditions. He is also an occasional guest lay-preacher at New Life Church, 5 Shuttle Street, Paisley PA1 1YD, Scotland.

Ms Jenny Kwai-Sim Leung moved from PRC China to Hong Kong at age 14 and started full-time work at this time as a garment factory production worker whilst taking evening high-school classes. Later she was able to switch over to full-time office-work. She has eight years' working experience as an internal auditor and accountant in both Hong Kong and PRC China. She is a Bachelor of Business (Accounting) graduate from Charles Sturt University (Wagga Wagga, Australia). She has published scholarly articles in International Journal of Economics and Accounting, International Journal of Social Economics, and Managerial Auditing Journal. 


\title{
On the Relationship between Catholicism and Marxism
}

\begin{abstract}
This article contains a previously unpublished essay of personal reflections on the relationship between Catholicism and Marxism. The essay includes a critique of the Social Teaching encyclicals written by Cardinal Joseph Ratzinger and Pope John Paul II in the 1980s. We will see how John Paul II subtly incorporated some of the key ideas of the liberation theologians into the official body of Roman Catholic Social Teaching after 1986. This article should help younger researchers who might be interested in but are struggling with Catholic Social Teaching and/or Marxism in either theoretical and/or practical realms. This is especially important given that some Marxist authors within critical accounting are near or past retirement age and there is a real risk that the understandings of Marxist theory which they had will be lost to the discipline. We also look at some potential research topic areas which a developing country-based researcher could profitably explore using a Marxist perspective with a special focus on Fiji Islands, Indonesia, and Singapore.
\end{abstract}

Keywords: Catholic Social Teaching; Critical accounting; Fiji Islands; John Paul II; Liberation theology; Marxian economics; Marxism; Roman Catholicism. 


\section{On the Relationship between Catholicism and Marxism}

\section{Introduction}

We hope that this article will inspire and inform younger and newer researchers who might be interested in but are struggling with either Catholic Social Teaching and/or Marxism in either theoretical and/or practical realms of life. Alternatively they might be wondering whether it is possible to existentially combine these two worldviews. We believe that this article is especially important and timely today (rather than, say, ten years ago) given that some well-known Marxist or Old-Left authors within critical accounting (e.g. Armstrong, Bryer, C. Cooper, D. Cooper, Hopper, Lehman, McKinstry, Merino, Neimark, and Tinker) are closing in on or past retirement age. We are concerned that there is a real risk that the understandings of Marxist theory which they had will be lost to the discipline as younger researchers choose the safer, less controversial, and more Politically Correct paths of Legitimacy and Stakeholder Theory.

Bryer's classic and brilliant 2006 article on Marxism and accounting (Bryer, 2006) has had only 132 citations since it was published (as at 1 March 2018) which surely suggests that newer researchers are not following in the footsteps of our distinguished Marxist scholars in the numbers or with the dedication which some of us might hope for. Similarly, other classic Marxist articles by Bryer (1999) ('Marxist Critique of FASB Conceptual Framework') and Tinker (1999) ('Mickey Marxism Rides Again') have had only 111 and 65 citations respectively (as at the same 2018 date). By contrast, Legitimacy Theory-based articles by O'Donovan (2002) and Deegan et al. (2002) have had as many as 1,157 and 1,130 citations respectively (also as at 1 March 2018). Although the Bryer (2006) article is four years younger than those two Legitimacy Theory articles we really can't see its citations reaching such heady numbers over the next four years. The reasons for the lack of interest by younger and newer researchers in Marxist Theory (which many might argue is way more sophisticated and intellectually strong and robust than is Legitimacy Theory, despite Deegan and Unerman's (2011, p. 322) assertion that the alleged difference between classical and bourgeois political economy theory is 'simplistic') might be worth exploring in future survey and/or interview-based research as we regard it as a worrying trend.

One reason for the trend might be that newer researchers often live in developing countries or are based in the west but grew up in developing countries; Marxism may be perceived to be too dangerous or risky to use in such countries (dangerous to the researchers' careers at least) because of the hegemony of hyper-capitalism and neo-liberalism which have 
gained dominance in Asia and Africa in the years following the fall of the Soviet Union (Singapore being a classic case in this regard). The communist hammer-and-sickle remains a banned symbol in Indonesia for example. ${ }^{1}$ Researchers from Russia and Eastern Europe might shy away from Marxism as unpleasant memories of life under their own communist regimes might still be too deep and must remain repressed. Similarly, the Chinese Cultural Revolution (1966-68) is still within living memory for many Chinese scholars or their parents lived through the experience and still recount tales of woe. The distinction between Marxism and Really Existing Communism is of course important here. Furthermore, researchers from developing countries may shy away from Marxism as they may perceive that it contradicts their own strongly-held Buddhist, Christian, Hindu, Muslim, Sikh and/or Taoist religious beliefs. This article may help such researchers to explore this issue further. We choose to study Catholic Social Teaching rather than the social teaching of other religions because we feel it is best to stick to what we understand best and also because in the 1980s Catholics, from the 'lowest' to the 'highest', had to deal with the emergence of various quasi-Marxisms in the form of Liberation Theology and the Poland Solidarity trade union.

In the next section we discuss Marxist Historical Materialism and Alienation Theory; and outline research agendas utilizing these theories which a developing country-based critical accounting researcher might profitably explore. We then show how a Marxist theory framework could be used instead of Legitimacy and Stakeholder Theory in analysing the results in a well-known article by Islam and Deegan (2008) about pressures imposed by multinational buyers on a Bangladeshi garment industry body and the reporting and disclosure choices which resulted from these pressures.

\section{Marxist Research Agenda for Developing Country Researchers}

Historical Materialism Theory refers to the succession of modes of production in a chain of historical development which began with primitive society, progressed through slave-society, feudalism, and capitalism to, in the hope and expectations of Marxists, socialist and later communist societies. Progression from one stage to another (which should not be viewed as a progression in any ethical sense or not until capitalism has been surpassed) occurs as the contradiction between opposites becomes untenable and the system breaks apart under the weight of its own internal contradiction(s). The transition from feudalism to capitalism is

\footnotetext{
${ }^{1}$ The owner of a rock-music merchandise shop in South Jakarta found out this fact two years ago when they were arrested by local police for trying to sell a tee-shirt of the German Heavy Metal band Kreator which featured a hammer-and-sickle. Source: http://www.blabbermouth.net/news/indonesian-store-owners-arrestedover-kreator-t-shirt-featuring-communism-symbol/ [accessed 2 March 2018].
} 
explained by Marx (1994b) as occurring due to traditional feudal relations in the countryside especially (but also in the towns) becoming 'fetters' (Marx, 1994b, p. 211) [1859] on the more advanced capitalist forces of production in the cities and towns; people had to be set free from the land and to 'motley feudal ties', to quote The Communist Manifesto (Marx and Engels, 1998, p. 53) [1848], so that capitalist production proper could begin (defined by 'cash nexus' or 'cash payment' (Marx and Engels, 1998, p. 53) [1848] dominating and in fact defining all relationships). Under capitalism proper labour-power itself becomes a marketable commodity and labourers must sell their labour-power afresh each period in order to survive. For capitalism to work, labourers must be legally and morally free (Tinker, 2002, p. 259) to move from town to town in search of employment and promotions (and ideally from country to country although modern passport controls put some boundaries upon this freedom). If we wanted to reduce the explanation of this process to its most concise form we would say the transition involves the replacement of 'motley feudal ties' with 'cash nexus' over all areas of life (Tinker, 2002, p. 259) except perhaps for the nuclear family (although even it is pressured and shaped by market forces (Tinker, 2002, p. 265)).

The key point for aspiring researchers to understand about this theory is that, although England's landlords began adopting and spreading the capitalist mentality from around $1750^{2}$, according to Bryer (2004), developing countries are only now going through this transition but in a sped-up and socially very disruptive way; as village subsistence farming communities give way to naked capitalism in and at the fringes of the major cities (side-byside with incredible poverty). In Fiji Islands ${ }^{3}$, we can see tourism replacing sugar production as the major industry. ${ }^{4}$ A comparison of the three towns around 30 kilometres apart in the western part of the main island, Nadi, Lautoka, and $\mathrm{Ba}$, is a very interesting exercise. Nadi (population ${ }^{5} 42,284$ ) is dominated by tourism in a way which might soon approach Bali proportions; Lautoka (the provincial administrative hub, population 52,500) 30.42 kilometres east of Nadi sees some tourists visit, especially ocean-cruisers letting their passengers stop for a few hours' shopping, but its economy and culture are not dominated by tourism dollars the

\footnotetext{
${ }^{2}$ Bryer (2004, p. 1) writes that: 'from around 1750, England's landlords played a pivotal role by adopting and then spreading the capitalist mentality and social relations by enclosures and changes in the management of their estates and tenants.'

${ }^{3}$ The Fiji Islands' discussion draws upon the first-mentioned author's experiences whilst working at University of Fiji, located on the Queen's Highway between Nadi and Lautoka, between May 2013 and December 2015 and that author's subsequent visit back to Fiji in July 2017.

${ }^{4}$ The ethnic mix of Fiji is: Indigenous Fijians 56.8\%, Fiji-Indians 37.5\%, Rotumans 1.2\%, and Others 4.5\%. The Fiji-Indians are mostly the descendants of indentured labourers brought to Fiji by the British to work on the colony's sugar plantations 100 to 140 years ago. Fiji became independent from Britain in 1970.

${ }^{5}$ Populations of Fijian cities and towns are accurate as at 2018 and are taken from the following website: http://worldpopulationreview.com/countries/fiji-population/cities/ [accessed 3 March 2018].
} 
way that Nadi's are. By contrast, almost no tourists visit Ba (population 14,596), 35.6 kilometres to the east of Lautoka, which is the centre of Western Fiji's small local Fiji-Indian manufacturing industry. Ba retains its slow traditional way-of-life (and the Indian atmosphere of its town-centre) to a much larger extent than Nadi or even Lautoka. The football (i.e. soccer) rivalry between $\mathrm{Nadi}$ and $\mathrm{Ba}$ sees tourist-town play heartland-town/ Indian manufacturing centre. Nadi even uses the Jetsetters nickname to reflect cosmopolitanism and an open economy and attitude. The Lautoka Blues football team has rivalries with both Nadi and $\mathrm{Ba}$ although the Nadi-Ba rivalry is probably the most significant football rivalry in Western Fiji. Hustling of tourists for money and drinks has eroded traditional indigenous Fijian village culture in Nadi and undermined traditional authority and protocol. The villages near to Nadi Town may be forced back into the hinterland so new hotels can be built and certainly the Fijian villagers are unlikely to receive their just share of the proceeds.

Academic research could explore the contradictions, tensions, and dilemmas of the transition to capitalism in Fiji and other developing countries and how this transition is both a blessing and a curse; but also irreversible. Indigenous Fijians long for a job in the tourist resorts, where they might have a five-day-holiday stretch followed by 25 days at work. Workers have one big night together in the pubs of Lautoka or Nadi before returning to their various villages stretched across the coast and hinterland until their five days is up. Research should explore the intersection of the global and the local; and the destruction of traditional cultures and old ways of humility, patience, and respect for elders. A Marxist perspective might analyse the Fijian indigenous village system (each village has a village council, headman, and assistant headman; only people of an extended family can live in one village with consent of the majority; houses and land can be passed on to family members but never annexed and sold separately; and non-indigenous people cannot live in the village). The village parodies traditional Fijian village life, which clings on to some extent if only in ritualized observances ${ }^{6}$ as people realize that real power lies in the economic realm ${ }^{7}$ and it is exercised always outside of the village boundaries. Villagers go to Nadi town-centre to drink beer, party, and hustle or sell handicrafts to foreign tourists; and there is the expression 'she

\footnotetext{
${ }^{6}$ An example of 'motley feudal ties' clinging on today in Nakavu Village near Nadi Town is the penalty imposed by village management on an 18-year-old village girl who was drinking kava earlier on a Sunday than is permitted. The prescribed penalty, designed to teach respect, was for her to wash her grandfather's grave. This story was relayed to the first-mentioned author by the former Lautoka, Nadi, and Fiji soccer player Henry Dyer who has served as both acting and assistant headman at Nakavu Village (see Figure 1 and 2).

${ }^{7}$ This is broadly correct but an oversimplification. Village headmen and the larger district's Paramount Chief, although not officially part of the government or ruling party, still maintain traditional symbolic, reputational, and political (with a lower-case $\mathrm{p}$ ) capital as the representatives of the traditional landowners.
} 
or he is good in the village and bad in the town' so each indigenous Fijian, especially the young, the curious, and the sociable, build up and manage complex dual identities.

\section{Insert Figures 1 and 2 about here}

The contemporary Fijian village is a strange mix of modern public-housing and traditional pre-modern village, a living paradox and a living contradiction which embodies both western liberal-democratic concepts of public-housing and centuries-old concepts of village and ancestral land. The government's requirement that villagers raise funds first before the government 'matches' it shows how Singapore's neo-liberal People's Action Party (PAP) regime is a role-model and inspiration throughout the whole of the Asia-Pacific (for better or for worse). This policy encourages the mentality of seeking donations from anyone and from everywhere, a glorified form of begging, whereas, if the village doubles as publichousing, we might question why the government only matches internal fund-raising rather than initiates funding (as it would do for major road projects, schools, and hospitals, which are all located outside of villages and which of course can be accessed by non-indigenous citizens). Of course humanities researchers will also be interested in these topic areas but business-school academics can focus more on the economic side or, to be more precise, the interaction between the economic and the social. ${ }^{8}$

According to the young Karl Marx of the 1844 Manuscripts, under the capitalist mode of production, the worker is literally alienation from the products produced and from the act of producing (Marx, 1975, p. 327). The proceeds from the sale of the products become realized surplus-value which, in its turn, becomes accumulated labour or, in other words, capital. The worker has no control over these areas of the capitalist's operations. The other two forms of alienation in the 1844 Manuscripts theory (Marx, 1975, pp. 329-30) are alienation from one's own 'species-being' or true-nature and from other people.

In Indonesia, we see a growing middle-class, which increasingly begins to look like the middle-class of the west with its pursuits, interests, materialistic attitudes, and detachment from communities, reliance on global brand-names, and increased use of English and adherence to Christianity and more liberal forms of Islam. We see large-scale elaborate hotels and shopping complexes funded by large-scale capital which are often not full and are

\footnotetext{
${ }^{8}$ Another fascinating event is the arrival of Chinese capital and businesspersons in the last decade with the traditional Indian Gujarati business community being subject to a new challenge after one hundred and twenty years of economic domination and cultural hegemony.
} 
inaccessible to many if not most locals. One hundred metres away from such places you can see shanty-towns of unimaginable poverty, as the Napalm Death band member Barney Greenway (from England) commented about Jakarta on the Global Metal DVD (2008). ${ }^{9}$ The Historical Materialism and Alienation Theories apply here as well. Research has documented thriving Indonesian underground punk music (Baulch, 2003, 2007; Prasetyo, 2017; Saefullah, 2017) and Heavy Metal music scenes (Baulch, 2003, 2007; James and Walsh, 2015, 2018; Saefullah, 2017; Wallach, 2008, 2011) but even these fall victim to entrepreneurialism and the marketing perspective. Islamic religious belief is mixed with punk and Heavy Metal in a bid to rescue Indonesian life from oppressive modernity and the corrupting influences of capitalism and consumerism (James and Walsh, 2018; Saefullah, 2017). These religious punks and metalheads (a legacy and product of the disintegration and fragmentation of a united left-wing in the years after the fall of the Suharto regime) should not be simplistically viewed as reactionary as western scholars might be tempted to see them. Indonesia differs from Fiji based on population, closeness to major world markets, and it has a large middleclass whereas in Fiji there is more a stark contrast between rich and poor and between the modern and the pre-modern.

Without a rural hinterland, the city-state of Singapore shows the effects of hypercapitalism and a benevolently paternalistic but ultimately authoritarian state which for a long while tried to be pro-free market and pro-family values but, when push came to shove (as with the casino licences issue), economics of course trumped family values. This clearly reflects the Marxist theory of the primacy of the economic base over the cultural, ethical, legal, ideological, and religious superstructure. The mistreatment and marginalization of foreign workers from poorer neighbouring countries can also be well-analysed using the related Marxist frameworks of Historical Materialism and Alienation. So, while Singapore is fully-capitalist, the rural hinterlands of neighbouring countries, and even the major cities, are in the process of transition. Singapore and Jakarta serve as beacons of light which attract people but the people arriving there are often soon exploited, mistreated, and disheartened. However, some find new forms of community such as the Indonesian warungs (mobile wooden street-food and provision stalls) where men gather to socialise in the evenings (and each warung even attracts its own 'regulars' like a pub or bar does in the west) (Wallach, 2008, pp. 77-8, 141-9, 153-5, 157-9). Warungs in Jakarta and other major Indonesian cities attract men from all over Indonesia, and so mentioning the names of remote towns can make

\footnotetext{
${ }^{9}$ This section appears from 58:59 to 59:12 on the Global Metal DVD.
} 
the speaker a new friend in a second. ${ }^{10}$ Women are usually largely excluded from these groups or keep a low profile to the back or in quiet corners as they don't want to intrude upon a male space. Women often work as bar-hostesses in dangdut music clubs servicing businessmen; their own boyfriends in the warungs cannot afford to attend such clubs or the even higher-priced karaoke bars where a room-and-hostess session might cost over one million rupiahs in Jakarta (USD72.80) or 30\%-40\% of a manufacturing worker's monthly salary. ${ }^{11}$

Some researchers may argue that most of the issues and contexts listed above are not business-school topic areas. ${ }^{12} \mathrm{We}$ can answer this objection on a number of fronts. Firstly, putting strict dividing walls between subject areas is a function of modern-day neoclassical economics, agency theory, Modern Finance Theory, and Positive Accounting Theory (although even the latter has a political cost hypothesis). In Marx's time no such barriers existed and he studied topics of economics, history, and sociology and he examined the connections between them (Tinker, 2002, p. 266). An analysis deliberately ignoring and shutting out non-accounting aspects will just replicate prevailing modern-day business-school dominant discourses. The contexts we mentioned explore the contradictions and tensions which in most cases are a product of globalization (a process already existing in Marx's time). Secondly, there are financial and economic implications associated with the areas we have discussed although in many cases it is more about exclusion from networks of production, distribution, and consumption as much as it is about inclusion. The picture of a burger and chicken nuggets, which is a bus-stand advertisement for McDonald's in front of the entrance to Nakavu Village in Martintar, Nadi, is oppressive because most of the indigenous Fijian village children will rarely be able to afford such food. (McDonald's is for the middle-class and business community who drive past on the Queen's Highway linking Nadi, the airport, and Lautoka). Thirdly, tourism is becoming a major industry in Fiji and we need to look at it seriously from an academic (including a business-school) perspective. One resort in Fiji has around 700 employees and 49 managers; it operates at a level of economy way above and beyond nearby towns and villages; it is like a city which has descended down

\footnotetext{
${ }^{10}$ Other informal post-modern community groups include Filipina maids congregating at Lucky Plaza Shopping Centre, Singapore on Sundays (an ironic name for a shopping centre as luck rarely comes these women's way) and, in Hong Kong, the Indonesian maids in hijabs who become more religious away-from-home and conduct Sunday religious study sessions on pavements in Mongkok, Kowloon.

11 The average monthly manufacturing workers' salary was 2,636,846 rupiahs (USD191.70) in the third quarter of 2017. Source: https://tradingeconomics.com/indonesia/wages-in-manufacturing [accessed 4 March 2018].

${ }^{12}$ Regarding business-school topic areas, see Mihret et al. (2010, 2012a, 2012b) for a Marxist perspective on internal auditing; James and Walsh (2017) for a Marxist perspective on sport management and marketing; and James et al. (2018) for a Marxist perspective on CSR reporting in Scottish football.
} 
from outer-space in terms of its connection with its surrounding environment. However, mostly indigenous Fijians work there and Fiji-Indians (also citizens of Fiji) are relegated to back-office jobs since the hopelessly essentialized image of Fijianness sold to overseas tourists only has room for indigenous Fijians; Fiji-Indians cannot enter that discourse although in many case their families have lived in Fiji for over a hundred years and were brought there by the British for sugar-plantation indentured labour and so are forever associated with the colonial project. Another interesting issue is the romanticisation of Fiji which Fiji-Indians have after they migrate to the developed world; in most cases they steadfastly refuse to cut their links to Fiji both in their self-imagining and in their regular activities. We thus have something of a double-migration or a double-translocation, one occurring recently and the other a hundred years ago. The hybrid identities which emerge are a hybrid product of three societies (at least). Fourthly, there is nothing to stop an accounting researcher publishing in non-accounting or even non-business journals in a free world.

We now show how a Marxist theory framework could be used instead of Legitimacy and Stakeholder Theory in analysing the results in a well-known article by Islam and Deegan (2008) about pressures imposed by multinational buyers on a Bangladeshi garment industry body Bangladesh Garment Manufacturers and Exporters Association or BGMEA (hereafter BGMEA) and the reporting and disclosure choices which resulted from these pressures.

We observe here a shallow, trivial theoretical framework (Legitimacy Theory but the fact that Stakeholder Theory and Institutional Theory are also used does not improve matters despite the authors' protestations), which is unable to contain the explosive power of the interview data (although it can 'explain' it) or the importance of the context.

We get the strange throw-away comments that legitimation strategies 'need to explicitly consider the specific national, historical and cultural context' (p. 853) (even though Legitimacy Theory itself does not mention culture) and that ' $[\mathrm{t}]$ heoretically, there is no apparent reason why the theories would be more appropriate in one national context as opposed to another' (p. 857). This last comment flies in the face of any type of commonsense and logic since one moment's thought should reveal to any researcher that Legitimacy Theory assumes a pluralistic developed western society (or an eastern society such as Hong Kong or Japan) which has a relatively free press; an affluent and educated middle-class; and a proliferation of NGOs and trade unions with real relative autonomy. Bangladesh would not fall into this category of country but there is no attempt early in the article (before the Results section) to model how the country works or how it fits within globalized capitalism; all we get are the stock-standard explanations of Legitimacy Theory and its two "complementary 
perspectives' (p. 853) which are Stakeholder Theory and Institutional Theory. To be fair the article tries to take into account 'the specific national, historical and cultural context' in the Results section but the best part of the article (the second-last paragraph of the last page $\mathrm{p}$. 871) occurs when the authors forget about their preferred theories for a moment and come up with stream-of-consciousness common-sense remarks about the global inequities that the case study data does very clearly reveal. For example, we get unscripted remarks about "power imbalance' (p. 871) because buying companies can 'dictate the behaviour they expect' (p. 871). Furthermore, the case data 'raise[s] issues about the responsibilities of powerful stakeholders when dealing with ... developing countries' (p. 871). Apart from the irritating two-word discursive nod to the theories ('powerful stakeholders'), this paragraph contains some incisive and brutally frank observations about the global inequities revealed by the case data. However, the theories had to be quietly put aside before such potent commentary could emerge. The weaker parts of the article are the predictable Little Jack Horner ${ }^{13}$ sections where the authors show how reporting of SEA activities by the BGMEA mirrors and follows (with a lag) lobbying actions by westerners in the USA and Canada on these very topics, as if this conclusion says anything meaningful beyond 'proving' the predictions of the theory in the most straight-forward and literal of fashions.

At various points the interviewed BGMEA executives are 'castigated' (our word) by the authors for not discussing 'any moral or ethical issues' (p. 854) associated with childlabour or other issues. This statement is careless and unnecessary; it fails to recognize that in developing countries Politically Correct 'virtue-signalling' is not yet in vogue and people may just prefer not to use words such as 'morality' and 'ethics' believing that actions speak louder than words and that (good) actions should be self-evidently seen as ethical.

Buried in the middle of a long quote (so that it is not too obvious) on page 864 , one interviewee expresses his/her frustration at the middle-class North American college students who lobby against child-labour and other human-rights and environmental issues in the west. $\mathrm{He} / \mathrm{she}$ explains that Bangladesh has no or minimal social-welfare and that a 15 or 16-yearold might work in the factory to support an extended family. Wages might appear low but the cost-of-living is much lower too, this interviewee adds. Being restrained by the triviality of the Legitimacy Theory framework, the authors fail to fully realize how important these comments are as they reflect the power imbalances and (virtue-) signalling mechanisms now inherent in modern global capitalism. The 'instructions' (and the accompanying discourse of

\footnotetext{
${ }^{13}$ According to the traditional nursery rhyme: Little Jack Horner sat in the corner, eating his Christmas pie / He put in his thumb, and pulled out a plum, and said, "What a good boy am I!"
} 
morality and ethics) proceed from west to east but the financial cost is largely borne in the east. When the 15 or 16-year-old leaves the factory because she/he is classified as a childlabourer and the family loses its only breadwinner that family's situation becomes much more precarious but this event fails to register on western radar. ${ }^{14}$

The developed world expects Bangladesh to replicate working conditions and legal structures which are not necessarily suitable or even possible given the economic situation of the country. We have a form of economic neo-colonialism where the effective rulers of the Bangladeshi garment industry issue 'edicts' from the safety and comfort of their developed world locales. If Bangladesh puts large sums of money into improving working and factory conditions (which prima facie is of course desirable) living conditions often begin to fall far behind the (relative) splendour of workplaces as money is limited and protestors in the west focus more upon working rather than living conditions. This creates a situation of further alienation and injustice as the children, unemployed, elderly, and disabled then encounter worse conditions at home compared to the almost opulent (by local standards) workplaces which, not having a job, they literally have no access to.

Legitimacy Theory distracts from the main issues by its myopic focus on legitimacy and SEA reporting and the alleged lagged causal relationship between the two. It assumes implicitly a western developed country context which the authors Islam and Deegan (2008) do not acknowledge. By contrast, Marx's Labour Theory of Value, Historical Materialism Theory, and Alienation Theory illustrate and explain, in a more complete and deeper way, the structures of global capitalism and neo-liberalism which create the contexts in west and east which allow the situations described in the article to occur and to become likely. We have a new economic form of colonialism working via an unofficial chain-of-command where western students protest in front of western media to start the ball rolling. Negative media reporting then shames western multinational buyers which then pressure the BGMEA. Lastly, we see the garment industry in Bangladesh implement policies to redress the situation so as to retain the support of western buyers and to silence the other detractors. The family we mentioned earlier, whose 15 or 16-year-old son or daughter is now banned from factory work is in a worse situation than it was in the beginning; but no-one in the west will know about such a situation as it is not considered newsworthy and goes unreported.

The data speaks about and to issues which are far more important than the main focus of the article which is how Legitimacy Theory 'explains' SEA reporting (with a lag) by the

\footnotetext{
${ }^{14}$ Of course no-one wants an 8 or 10 or 12 -year-old working in a factory. This point should be obvious.
} 
BGMEA which, in itself, is a fairly non-interesting and predictable finding (or at least a finding of secondary importance). The theory constrains and limits the minds and worldviews of the researchers, pegging them in, and preventing important discussion in areas where the theory fails to tread (Tinker, 2002, pp. 264, 268). Do the interviewed BGMEA executives really want to be perceived as 'legitimate' or just to survive and to live at peace in the local setting in which they were most probably born?

\section{Unpublished Essay (written circa 2009-2010 with minor editorial updates)}

The following is a previously unpublished essay of personal reflections on the relationship between Catholicism and Marxism. The essay includes a critique of the encyclicals written by the then Cardinal Joseph Ratzinger (later Pope Benedict XVI) and Pope John Paul II in the 1980s namely Instructions on Certain Aspects of the 'Theology of Liberation' (Ratzinger and Bovone, n/d) and Sollicitudo rei socialis [On Social Concern] (John Paul II, n/d). It is worth critiquing these documents as, in Stourton's (2006, p. 193) words, '[m]ost modern popes are remembered by their encyclicals'.

The then Cardinal Joseph Ratzinger's writings on Liberation Theology, as mentioned in James and Leung (2017, chap. 3), are fairly superficial and do not represent a genuine attempt to sincerely engage with the theoretical perspective being discussed. His comment on Marxism as an 'atheistic ideology that depresses workers' rights' is incorrect. If there is atheism in Marx we believe that this was more Marx's personal and consciously held view than an integral and necessary part of Marxism's theoretical structure. It was Marx (1994a, p. 28) [1844] himself who wrote of religion as 'the spirit of a world without spirit' (Michel Foucault's preferred translation) in 'An Introduction to "Toward a Critique of Hegel's Philosophy of Right", (as cited by Michel Foucault in his late-1970s writings on the Iranian Revolution). Those who claim that Marx should not regard the economy as primary nor should atheism be the main part of his philosophy cannot have it both ways. If the economy is the primary, meaning most important, aspect of his theory (Ollman, 1976), then religion must be secondary, i.e. in conventional Marxist terms 'relegated to the superstructure' as it tends to be also in the world of modern neo-classical economics. If religion is 'relegated to the superstructure', can we dare to think that Marx might allow his supporters and followers some measure of religious freedom? In Engels' (1987) [1845] The Condition of the Working Class in England, the young Engels' sincere compassion for the oppressed Irish poor of newly industrialized Manchester is the primary impression that the reader takes away from the text. We are confronted in this text with a very ethical and spiritual view of the world. 
Similarly, in the 1844 Manuscripts, the young Marx (1975) [1844] presented a theory of 'alienation' where he lambasted capitalism for putting in place working and legal conditions that prevented the worker from realizing her/his complete potential as not only a worker but as a human being. Marx $(1976,1981)$ continued this humanitarian perspective in the chapters of his later work Capital, especially Chapters 10 and 15 of Volume 1 and Chapter 5 of Volume 3, where he was extremely hostile towards capitalist employers who abused and mistreated workers. His descriptions of the exploitation of labour, especially that of women and children, under capitalism, and the pointless and painful early deaths that resulted, are extremely moving and reveal Marx's humanitarian ethics. As the French communist philosopher Louis Althusser (2005, p. 82) [1965] writes, it was Marx's 'extraordinary sensitivity to the concrete which gave such force of conviction and revelation to each of his encounters with reality'. Bertie Ollman (1976, chap. 4, pp. 41-52) is correct to say that Marx's ethics work continuously and are expressed through his writing and his terminology rather than being a separate, detachable, and easily identifiable part of his overall theory. We would agree with a position that Althusser (2005, p. 52, emphasis original) rejects: 'Capital is an ethical theory, the silent philosophy of which is openly spoken in Marx's Early Works'. Marx might, officially, relegate ethics to the superstructure, but what he was referring to was bourgeois ethics rather than what Engels (1976, p. 117) in Anti-Duhring termed 'the proletarian morality of the future'. Bourgeois ethics is a pure intellectual category in that it does not have as its goal the transformation of society. It cannot penetrate the economic world since its inventors benefit from the economic status quo and do not want to see the underlying 'relations of production' disturbed.

John Paul II (1991, Section 27, p.41) states that, under communism, 'basic virtues of economic life, such as truthfulness, trustworthiness and hard work were denigrated'. This statement is wrong in regards Soviet and Chinese communism where most commentators claim that the state pushed people to work too hard in order to meet unrealistically high production targets as the rates of industrialization were sped up to unreasonable and inhumane levels. One of Leon Trotsky's (2004, pp. 25-34) [1937] main criticisms of Stalin's leadership, we should recall, was the speed and the forced nature of the collectivization of agriculture (Mosley, 1972, pp. 94, 107). Some people may have not worked as hard or as smart as they should have done under communism because the incentives of capitalism are absent. However, this cannot be blamed upon the state or the system but upon human greed (a point made by Michael Blewett, a building industry supervisor in Kalgoorlie, Western Australia and friend of the first-mentioned author, in personal conversation with the first- 
mentioned author, 23 July 2009). As Mosley (1972, p. 105) writes, 'it had been believed [by Marxists] that the working class, when oppression had been removed, would by some sort of grace become altruistic and not suffer from the sins of greed and self-interest that had bedevilled its oppressors'. The statement of John Paul II cited earlier also fails to distinguish Polish/Soviet Communism from Marxism. Anyone who has read Marx would dispute the assertion that he denigrated either hard work or truthfulness.

We do not agree with the theory of the 'epistemological-break' or 'hard-break' (Tinker, 2002, p. 265) proposed by Althusser (2005, pp. 13, 33) where he contrasted Marx's earlier 'ideological' works with his later works that were, allegedly, purely 'scientific' (Althusser, 2005, p. 34) (Tinker, 2002, pp. 263, 265). He argued that 'The German Ideology' of 18451846 marked the first work 'after the break' (Althusser, 2005, p. 33). Although Marx's emphases and use of terms changed over time, alienation as a theory never disappeared from his work (Ollman, 1976). However, in Capital and other later works, he simply used this term less frequently. The term is not used as often, but the idea remains (Ollman, 1976). In Socialism: Utopian and Scientific, the mature Engels (2004, chap. 3, pp. 57-9) [1880] discusses alienation and the Marxist theory of value in the same few pages, although he does not use the specific term 'alienation'. Not much should be read into the dropping of the term 'alienation' by the mature Marx or by the mature Engels. Marx never renounced his earlier humanitarian and philosophical tendencies. His greatest theoretical achievement (Engels, 2004, chap. 2, pp. 52-3; Sy and Tinker, 2011, p. 148), the theory of 'surplus-value as unpaid labour time', presented in detail in Capital Volume 1, contains the theory of alienation within it as an integral aspect. If the employer appropriates labour time without payment, then we have the workers' literal alienation from the products produced and from the act of producing (Marx, 1975, p. 327) [1844]. The proceeds from the sale of the products become realized surplus-value which, in its turn, becomes accumulated labour or, in other words, capital. The worker has no control over these areas of the capitalist's operations. The other two forms of alienation in the 1844 Manuscripts theory (Marx, 1975, pp. 329-30), alienation from one's own 'species-being' and from other people, follow on from the first two forms of alienation. The last two forms are clearly a consequence of the extraction and appropriation of surplusvalue by the capitalist from the workers. It can even be said that the theories of alienation and surplus-value are the same theory presented in different terminology (philosophical and economic, respectively) and from a different perspective (individual worker versus whole-offactory). The latter theory specifically includes the former. 
Cardinal Ratzinger is incorrect to say that the class struggle is all there is to Marxism and that, for Marx, 'class struggle is everything'. We have four arguments against this view and we shall go through these one by one. Firstly, the class struggle was not 'everything' for Marx. Two raindrops racing each other down a window or two birds flying across the sky, for example, cannot be explained by class struggle and any Marxist that did so would be completely foolish. Clearly, not all social struggles can be explained meaningfully on the basis that class struggle is the principal contradiction. Social struggles in this category might well include: domestic violence within the working-class family; sexual killers and police investigations; and bullying between school-children of the same age bracket, gender, and social class. However, workplace struggles generally involve oppression by the capitalist employer, either directly or via the chain-of-command, of individual workers and/or of the collective worker. The new second-edition of the book by James and Leung (2017) presents several micro-cases that reveal such employer exploitation and oppression in the Australian construction industry (see also Leung et al., 2010a, 2010b, 2011 by the same authors). In these micro-cases the struggles have a class element because of the way that Marx defines 'classes'. The members of the bourgeoisie own the means of production and capital whereas the members of the proletariat do not. Nearly all the implications of Marxism flow from this statement of reality. The members of this latter group are forced to sell their labour-power daily in the market-place in order to survive. As such, the members of these two classes have divergent interests with the maximization of surplus-value being much more appealing to the members of the bourgeoisie than to the members of the proletariat. As Trotsky (cited in Mosley, 1972, p. 74) writes, class struggle can be defined simply as 'the struggle for surplusproduct', i.e. surplus-value. This can include the struggle for non-monetary benefits payable by the employer out of the surplus-value, such as extra lunchrooms and toilets; improved working conditions; and better onsite safety (from the construction industry perspective). Clearly, these divergent interests between the classes will, on occasion, break out in obvious and manifest forms of 'struggle' which, for the sake of clarity, we can call 'class struggle'.

The Marxist concept of 'class struggle' should not become a reified brand-name, with the two words seen as permanently joined together as part of the same signifier. Class struggle is simply a struggle between classes, sometimes visible struggle and sometimes veiled or even latent struggle, caused by the two classes attempting to further their own interests and utilizing their own wills and resources towards achieving these ends. This is a very practical everyday thing. There is nothing ideological about this. This was Marx's point. As Althusser (2005, pp. 74-86) writes, Marx and Engels undertook huge efforts to free 
themselves from Hegelianism and other German idealist ideologies so as to confront directly the harsh realities of the socially stratified real-world. Marx met the realities of politics in France in the early 1840s whilst Engels discovered the reality of working-class life under capitalism in Manchester, England around the same time. German idealist philosophy held no more appeal for either author after these life-transforming experiences. As Althusser (2005, p. 78) writes, there were economists in England, at the time of the young Marx, because there was a real economy there, and there was political theory in France because there was real politics there. Germany remained backward and its philosophers had retreated completely into idealist philosophy. Ratzinger does not acknowledge, or apparently grasp, the basic realities expressed here since he refuses to view Marxism as anything but an 'ideology' because it did not originate from within the Church and is expressed in secular language.

Secondly, the end goal of class struggle, for Marx, was always the establishment of a fairer, kinder, more just and more equitable society where every person, rather than just the rich, are able to fully realize their potential on a daily basis (Mosley, 1972, p. 14). We should never lose sight of this. As Mao Zedong made clear, class struggle would continue under socialism (the age of the 'dictatorship of the proletariat') but not under communism. The end goal for Marx is the same end goal, pretty much, as the one believed in by Roman Catholics and called 'the Kingdom of God'. John Paul II and the four Nicaraguan priests, referred to in James and Leung (2017, chap. 3), who also served as ministers in the Sandinista Government, did not disagree over end goals. They disagreed only over means and 'ideologies'. The end goal, for Marx, is also the abolition of all exploiting classes which, as claimed by Brezhnev (1975, p. 236), had been 'long done away with' in the Soviet Union by 1972. Whether Brezhnev is correct is the matter of some debate. What the Soviet Union and China did, during the communist eras in those countries, was to centralize the means of production and take it out of the hands of the bourgeoisie, including the rural bourgeoisie (Feather, 1963, pp. 110-1). When Stalin introduced the policy of 'exterminating the kulaks as a class', philosopher Slavoj Žižek (2008) is correct to point out that this meant destroying the kulaks (rich peasants) as a class and not as individuals. They were no longer to be permitted to function as an exploiting class in relation to the middling and the poorer peasants and in relation to the means of production. This need not have involved the physical liquidation of individuals. It could have been achieved more simply by forcing the kulaks into the same economic position as the other classes of peasant.

The Marxist doctrine of class struggle purely asserts that, under capitalism, the members of the bourgeoisie (those who own capital and the means of production) have 
divergent interests to the members of the proletariat. Because of these divergent interests, capitalist bourgeois business owners sometimes exploit, oppress, and marginalize individual workers and/or the collective worker (McKinstry, 2007). Class struggle occurs in the factory as the bosses place their demands and requirements upon the workers. Most workplaces resemble dictatorships more closely than they resemble democracies.

Thirdly, the Roman Catholic literature wrongly assumes that only members of the proletariat engage in, or are tempted to engage in, acts of class struggle. In fact it was the bourgeoisie that began class struggle by imposing shocking working conditions upon the proletariat in the early years of capitalism. Before that, as referred to by James and Leung (2017, chap. 9) in those authors' discussion of their 'Wollongong hotel' micro-case, there was a long process of 'primitive accumulation' (Engels, 2004, chap. 3, pp. 58-9; Marx, 1976, pp. 873-940) whereby the peasants were progressively forced off the land and land was congregated in fewer and fewer hands. ${ }^{15}$ This primitive accumulation was needed to prepare the ground for a fully-fledged capitalist economic system characterized by generalized commodity production and the generalized exploitation of wage-labour.

Fourthly, the Roman Catholic literature fails to appreciate that, whilst class struggle is undoubtedly an important concept in Marxism, classes are aggregate social groupings. Marxism does not at all require that a member of the proletariat exhibit rudeness, hostility or unfriendliness towards a member of another social class in social, community, business or religious contexts. Marxism is not about individual struggle per se but about struggle between aggregate social groupings with diverse interests. Marxists also look forward to the world which is to come (The Epistle of St Paul the Apostle to the Hebrews 13:14) and speed its coming (II Peter 3:12). It would not be a good advertisement for socialism if Marxists were generally regarded as rude and hostile people living lifestyles of hostility and hatred. We can recall the polite and constructive manner of Soviet Union diplomats overseas from Gromyko to Malenkov to Gorbachev. Edward Crankshaw (1959, p. 46) recalls Georgy Malenkov's successful trip to London, not long after Stalin's death, where he apparently 'exuded confidence and charm' and was 'much more human, flexible, and swift-witted than his photographs suggested'. Simon Montefiore (2005) in Stalin: Court of the Red Tsar reports that, in his later years, Malenkov converted to Christianity, as did his daughter, who has since spent part of her personal wealth building churches throughout the former Soviet Union. An acceptance of the notion of class struggle does not mean, as Ratzinger assumes it does, that

\footnotetext{
${ }^{15}$ For a fictional novel with the Scottish Highland Clearances as context and backdrop we strongly recommend Broken Promises Never Die by the Paisley-based writer Lachlan 'Lachie' Steele (Steele, 2011).
} 
workers and bosses could not reverentially and respectfully share together in the Eucharist sacrament on a Sunday. Belief in class struggle does not mean, to quote Ratzinger and Bovone (n/d, Part X, Section 16, p. 31), that 'the unity of the Church is radically denied'. When a person takes Eucharist, she/he is not acting in her/his class role at that particular precise moment. Most people are not thinking about class struggle every minute of the day, in non-revolutionary settings, nor does class struggle define any one individual's identity in every significant respect. Although the class struggle does go on continuously (there is a McDonald's Restaurant and a BP service-station open at least somewhere in the world whilst we are sleeping), a person can choose to respectfully honour the Eucharist in church for however number of minutes that might take. ${ }^{16}$

As stated previously, we believe that Marx's greatest theoretical achievement (Engels, 2004, chap. 2, pp. 52-3; Sy and Tinker, 2011, p. 148) is the theory of surplus-value which explains how value is created in the factory and how this value is appropriated, without adequate compensation, by the professional managements or by the owners of capitalist business enterprises. Nowhere does the Roman Catholic literature refer to or acknowledge this important and key theory. Without this theory the remnants of the skeleton of Marxism would begin to look like ... 'ideology'. The end goal of Marxism is to create a free, just, kind, and harmonious society where the worker regains her/his control over the products of production and the act of producing. Surplus-value is no longer appropriated (or at least only to the bare minimum required for reproduction and expansion) and alienation is removed once we no longer have the capitalist mode of production. This is only the logical conclusion of the application of Marx's economic concepts to economic, social, and political problems. Class struggle must be seen as a means to an end. There is no reason why peaceful protests and even prayer could not be used by a Roman Catholic-Marxist as tools or instruments of class struggle. However, it would still be class struggle as most workplace exploitation and oppression is inflicted by the powerful upon the powerless or by the company owner or senior managers upon the workers. This is class struggle, by definition, even if we choose not to use the term. A fired ex-employee who shoots her/his boss in a fit of rage is engaging in an act of class struggle although that does not mean that this action is smart or wise or commendable. To deny that there is something intrinsically different, in essence, between the positions of the bourgeoisie and the proletariat is disingenuous, wrong-headed, counterproductive, false, and potentially harmful. Such a denial always empowers the already

\footnotetext{
${ }^{16}$ Our maintained position is that the Church (both local and global) is a valid and important institution in society. Debate on this issue is outside the scope of the present essay.
} 
powerful by assuming that both parties to a confrontation start out as equals with equal rights and no important shared history of conflict. This is why the position of the right-wing Christian (John Paul II does not fit into this category) seems to us untenable: it removes people out of society and out of history. The Catholic Social Teaching of Ratzinger and John Paul II finds itself in a bind here, of its own making, since, on the one hand, it denies the validity of class struggle and, on the other hand, it affirms it by telling people not to engage in it.

John Paul II is not so completely naïve or fraudulent that he denies the existence of classes in society. However, by refusing to acknowledge the validity of class struggle (or even its existence) he quietly affirms the existing order of the world whilst, simultaneously, condemning the injustices that he observes all around him many of which are the products or by-products of capitalism. He refuses to directly link poverty with capitalism; with the stratified nature of society; and with the stratified nature of workplace relations. In the end, and it is painful to say this, writing as Christian believers, Roman Catholic Social Teaching, if this is defined as excluding Liberation Theology, consists of not much more than nice words and well wishes. It limits all of our acceptable actions in this world to marketplace transactions and private acts of charity and compassion undertaken by individuals, religious groups or NGOs. Anything else is 'violent ideological Marxist revolutionary action' that can only be seen as harmful and leading directly to totalitarianism. There seems to be something missing in this worldview. John Paul II denies the 'political' in his writings (as, of course, Cardinal Ratzinger does also but in a more clumsy and less nuanced way) while, simultaneously, showing that he is acutely aware of it when he sides with the Polish Solidarity trade union against the Communist government of Poland. ${ }^{17}$ Is it a case of 'do as I do not what I say'? We would hope so. Stourton $(2006$, p. 4) is correct when he says that 'John Paul was, famously, a bundle of paradoxes; he defied every attempt to put him in an ideological box, and he could be equally bewildering to his admirers and his detractors'. We fall into the first said category of individuals (the admirers) and we do admit to feelings of bewilderment if not utter confusion. It seems that John Paul II allows himself and Polish Catholics the right to actively get involved in changing the world, a right that that he denies to the Latin American Catholics so that they might develop more 'patience' and 'forbearance'

\footnotetext{
${ }^{17}$ For the class struggle to remain the principal contradiction in that particular social struggle, we must assume that the Solidarity trade union was a genuine proletariat movement whereas the communist government of Poland no longer was (or never was). Or we can assert that this was a social struggle where class struggle was not its dominant aspect (Davis, 1978, cited in Avineri, 1991, p. 646). In other words, most people just wanted to be free of what they perceived to be an authoritarian regime.
} 
(John Paul II, 1991, Section 25, p. 38; see also Ratzinger and Bovone, n/d, Part VII, Section 3, p. 18). In John Paul II's (1991, Section 25, p. 38) words, '[b]y presuming to anticipate judgement here and now, man [sic] puts himself in the place of God and sets himself [sic] against the patience of God'. Furthermore, John Paul II (n/d, Section 48, p. 92, emphasis original) states: 'The Church well knows that no temporal achievement is to be identified with the Kingdom of God, but that all such achievements simply reflect and in a sense anticipate the glory of the Kingdom'. The meaning here seems to be that (a) we have to wait for the Kingdom of God, but (b) acts of charity and kindnesses can usher in the Kingdom. However, according to this worldview, 'political' acts of class struggle at best can only anticipate the Kingdom (because some aspect of inflicting judgement on others is involved). There seem to be several problems here. One significant problem is that the two categories are not mutually exclusive. An act of charity could also be an act of class struggle (and does not necessarily involve inflicting judgement upon others), e.g. financially assisting a trade union leader and her/his family; or sheltering and providing for a priest who is also a liberation theologian; or offering assistance to the unemployed or to poorly-paid workers or to striking workers. Indirectly, most acts of charity assist members of the proletariat and so they assist them to further their own interests. Indirectly, then, they are acts of class struggle (albeit non-violent acts) independently of the giver's intentions.

John Paul II might say that the crucial point is your motivation for helping. However, such an argument would not seem to have biblical support. For example, the Parable of the Good Samaritan (St Luke 10:25-37) never discusses the motives of the generous giver. Also, as stated, if the act helps members of the proletariat then the intention does not seem altogether relevant. Stalin took this point to its logical conclusion with his theories of the 'objective meaning of one's acts' and 'objective guilt' (Žižek, 2008). We are reminded of the bumper sticker showing a dancing stripper and the words 'I support single mums'. One of the sources of humour here is the Stalinist insight that the person is making a correct statement: he is, literally, supporting single mums with his payments of cash at the bar or to the women directly (as well as obviously supporting the capitalist club- or bar-owner). Theologically, the idea that political acts which directly help the proletariat at best only 'anticipate' the Kingdom, rather than actually usher in the Kingdom, does not sit well with Jesus' statements that 'if I with the finger of God cast out devils, no doubt the kingdom of God is come upon you' (St Luke 11:20) and 'the Kingdom of God is within you' (St Luke 17:21b). ${ }^{18}$

\footnotetext{
${ }^{18}$ All scripture quotations are from the King James Version (KJV) unless otherwise stated.
} 
Possibly, the Poles were permitted more leeway than the Latin Americans by the Roman Church hierarchy because the Poles were part of a more disciplined and hierarchical Church (Stourton, 2006). This fact may well lie at the heart of John Paul II's thinking. It was harder to control the Latin Americans because of distance from Rome and the Church hierarchy did not want to see a rebellious Latin American Church split from the European Church, a split which, if it had happened, would have proved as monumental as the split between Roman Catholics and Protestants (Stourton, 2006). However, it puts Latin American Catholics in the infuriating position of not being permitted to legally act against injustices perpetrated by the existing economic and social order.

In Sollicitudo rei socialis [On Social Concern], John Paul II, a self-educated philosopher as well as a theologian and a Pole who had personally lived under both the Nazi and Polish Communist regimes, provides a much more sophisticated, nuanced, and dialectical analysis of Liberation Theology than that provided by Ratzinger and Bovone (n/d). In John Paul II's documents we can observe him subtly 'co-opting' some of the less politically and theologically confronting doctrines of the liberation theologians as part of the Church's official body of RC Social Teaching (for example, 'preferential option for the poor' and 'sinful structures'). He recognizes that there is truth there, amidst what he sees as distortions and error. Commendably, John Paul II demonstrates his ability to learn from all sources, even though we wish that he had gone somewhat further. However, we wonder whether all such sources are properly acknowledged. Popes tend to cite only scripture; the writings of other popes; and (post-1965) the documents of the Second Vatican Council. John Paul II keeps up this tradition in this document.

The (untrue) myth of the Russian Revolution as being 'violent' is also frequently exploited in Roman Catholic literature. For example, the devotional and educational minibook Our Lady of Fatima refers to 'the violent Communist revolution' (Etling, 2005, p. 6). In fact, the revolution itself was remarkably bloodless (Mosley, 1972, p. 63; Reed, 1977 [1926]). Mosley (1972, p. 63) lists the total casualties as ten people, whilst Taylor (1977, p. xvi [1964]) lists it as six. Life in Petrograd (formerly St Petersburg) and Moscow, let alone in the rural areas, continued on as normal. Few people were even aware that a revolution had occurred. The bloody violence occurred in the subsequent Civil War and the Bolsheviks could not be blamed for wanting to actively defend their new state against the hostile coalition of local and foreign White Army forces. We cite two paragraphs from A.J.P. Taylor's 1964 Introduction to Reed's (1977) book to make our point (Taylor, 1977, pp. xvixvii): 


\begin{abstract}
"One sailor was killed when his rifle went off in his hand. Four Red Guards and one sailor were killed by stray bullets. That was the total death toll on this historic day. Most people in Petrograd did not even know that a revolution was taking place. The trams were running, the fashionable restaurants were crowded, the theatres were crowded and Chaliapin was singing at the Opera. The Red Guards kept away from the smart quarter or walked modestly in the gutter.

"The revolutionary military committee had planned a desperate resistance against a fierce attack by the provisional government. There was no such attack. Kerensky fled early in the day, protected by the Stars and Stripes, an anticipation perhaps of the much later Cold War. The other members of the provisional government sat helplessly in the Winter Palace. Red Guards took over the Post Office and the principal government buildings. Adhering strictly to programme, they did not reach the Winter Palace until six in the evening. Even then they did not attack it at all seriously. Red Guards filtered in through the kitchen entrance and took over the Palace without a struggle. At 2.25a.m. on the morning of 8 November Antonov, a member of the military revolutionary committee, broke into the room where the provisional government was still sitting and shouted: 'In the name of the Military Revolutionary Committee I declare you all under arrest'. Such was the end of old Russia”.
\end{abstract}

Old Russia, in the form of Kerensky's provisional government, definitely the 'weakest link' in the chain of European bourgeois governments at the time, ended with a whimper and there was no violence to speak of. The Paris Commune of 1871 put up a much stronger fight in its last hours. Where is the violent revolution? It seems that the Church is confusing the events of 1905, when Father Gapon's peaceful protestors were fired upon by Tsarist troops (Mosley, 1972, p. 25) with the events of October 1917. The Tsarist government, even as late as 1905, was a much more dangerous and formidable foe than Kerensky's provisional government, composed of liberals and moderate socialists, was in November 1917. To use a footballing analogy, if the Tsarist government was Arsenal and the Bolsheviks were Leeds United (or perhaps Millwall), then the Kerensky government was strictly non-league.

Closely connected to the point made in the Roman Catholic literature about the violent nature of the Russian Revolution is the argument that Marxism, by a process of cause and effect, always leads to totalitarianism in practice. This argument ignores the obvious points of difference between Soviet/Polish Communism and Marxism. It also fails to recognize that, in Marxist theory, the term 'the dictatorship of the proletariat' refers to a new socialist revolutionary government being forced to be relatively strict towards those bourgeois forces which aim to destabilize the government and restore capitalism. The dictatorship of the proletariat was never intended to be a permanent totalitarian state with complete licence to persecute and harass anyone coming within its sphere of influence. Russian Bolshevik leaders V.I. Lenin and Leon Trotsky had an original vision for the new socialist Russian state that was liberal and humanitarian; it was to be a place where literature and the arts flourished and where discrimination would no longer be tolerated. Mosley (1972, p. 16) writes that ' $[\mathrm{h}] \mathrm{e}$ [Trotsky] cared, and cared violently, for "the whole effort and intention of mankind" and 
'cared for mankind, ultimately, more than for dogmatic Marxism'. It was why he became part of the Left Opposition in the Soviet Union in 1926-27 and why he was later forced to leave the Soviet Union and then was murdered by a Stalinist agent in Mexico City in 1940. Trotsky's original humanitarian and liberal vision for socialist Russia can be clearly comprehended and felt even today in 2018 by reading his 1924 book Literature and Revolution (Trotsky, 2005) [1924].

Engels stated clearly at the end of his Introduction (written on 18 March 1891) to Marx's (1998) [1871] The Civil War in France that if 'you want to know what this dictatorship [of the proletariat] looks like ... Look at the Paris Commune. That was the Dictatorship of the Proletariat' (p. 18). The egalitarian, harmonious, liberal, and peaceable Paris Commune was a short-lived bona fide workers' state that ruled Paris from 18 March (more formally, from 28 March) to 28 May 1871. The Paris Commune was so weak that it was not able to prevent itself being destroyed by French bourgeois forces within the very first three months of its existence. The Paris Commune is the only historical example that Engels provides to illustrate Marx's concept of 'the dictatorship of the proletariat'. How can the Paris Commune be the blueprint for totalitarianism?

Despite all the rhetoric to the contrary in Catholic Social Teaching documents, we believe that Catholicism and Marxism have very similar views on the nature of the human being. For Catholicism, a human being is created 'in the image of God' (Genesis 1:26, 1:27a, 9:6b), with all that entails. For the young Marx of the 1844 Manuscripts (and for the French existentialist philosopher Jean-Paul Sartre in Being and Nothingness (2006) [1943]), a human being is unique as a knowing, thinking, feeling, perceiving, and acting subject and unique among the animals as one who can create the world around her/him in response to purposeful planning and, by so doing, create herself/himself existentially through the transformation of her/his physical world by labour (Ollman, 1976, chaps. 7-17, pp. 73-127). In Sartrean terminology, a human being is a 'being-for-itself' whereas other animals and created objects are mere 'being-in-itselfs' (Sartre, 2006). Both of the perspectives, Catholic and Marxist, are remarkably similar if we unpack what Catholics mean by 'created in the image of God'. It means created in the 'image of God' as a person who, like each of the three persons of the divine Trinity, can plan, think, perceive, feel, and act, and as one who is able to transform the physical world in response to purposeful planning. To be created in the image of God means to have all of the normal characteristics of personhood. We recall that the biblical character Cain was asked to 'tillest the ground' (Genesis 4:12) and, before that, Adam and Eve were commanded to 'replenish the earth, and subdue it: and have dominion over the fish of the sea, 
and over the fowl of the air, and over every living thing that moveth upon the earth' (Genesis 1:28). Of course, human beings are following God the Father's example here since 'God blessed the seventh day, and sanctified it: because that in it he had rested from all his work which God created and made' (Genesis 2:3). We see that planning, knowing, thinking, perceiving, and labouring are integral to both views about the nature of human beings. Both views point to the uniqueness of human beings and for the same reasons. Although Catholics might believe that the characteristics of human beings were given directly by God, while many Marxists perceive these characteristics to be evolutionary traits, this point should not be given undue emphasis. The more important point is the similarities in the two points of view.

\section{Conclusion}

Our conclusion is that it is completely possible, although at times existentially challenging, to be a Roman Catholic-Marxist. We have seen how John Paul II subtly incorporated some of the key ideas of the liberation theologians into the official body of Roman Catholic Social Teaching after 1986. The lack of spiritual ballast was probably one of the weaknesses of the Soviet and Eastern European states. It is interesting to note that the last living former leader of the Soviet Union, Mikhail Gorbachev, introduced John Paul II to his [Gorbachev's] wife Raisa as 'the greatest moral authority on earth'. In 2009, twenty years after the fall of communism in the Soviet Union, international newspapers quietly reported that Gorbachev had been observed praying at the tomb of St Francis of Assisi. Is this an admission by the now elderly former leader of a once great state that the founding Bolsheviks might have, officially, got it wrong about 'religion'? It is, indeed, the spirit of a world without spirit. The words were there in the canon all along. 


\section{References}

Althusser, L. (2005) [1965] For Marx, Verso, London and New York, NY.

Avineri, S. (1991), 'Marxism and nationalism', Journal of Contemporary History, Vol. 26, Nos. 3-4, pp.637-657.

Baulch, E. (2003), 'Gesturing elsewhere? The identity politics of the Balinese death/thrash metal scene', Popular Music, Vol. 22, No. 2, pp.195-215.

Baulch, E. (2007) Making Scenes: Reggae, Punk, and Death Metal in 1990s Bali, Duke University Press, Durham, NC.

Brezhnev, L. (1975), 'Speech at the $15^{\text {th }}$ congress of the trade unions of the USSR, March 20, 1972', in: Our Course: Peace and Socialism, Novosti Press Agency Publishing House, Moscow, pp.232-252.

Bryer, R.A. (1999), 'A Marxist critique of the FASB's conceptual framework', Critical Perspectives on Accounting, Vol. 10, No. 5, pp.551-589.

Bryer, R.A. (2004), 'The roots of modern capitalism: A Marxist accounting history of the origins and consequences of capitalist landlords in England', Accounting Historians Journal, Vol. 31, No. 1, pp.1-56.

Bryer, R.A. (2006), 'Accounting and control of the labour process', Critical Perspectives on Accounting, Vol. 17, No. 5, pp.551-598.

Crankshaw, E. (1959) Khrushchev's Russia, Penguin Books, Harmondsworth, England.

Davis, H.B. (1978) Towards a Marxist Theory of Nationalism, Monthly Review Press, London and New York, NY.

Deegan, C. and Unerman, J. (2011) Financial Accounting Theory, second European edition, McGraw-Hill Higher Education, Maidenhead, England.

Deegan, C., Rankin, M. and Tobin, J. (2002), 'An examination of the corporate social and environmental disclosures of BHP from 1983-1997: A test of legitimacy theory', Accounting, Auditing \& Accountability Journal, Vol. 15, No. 3, pp.312-343.

Engels, F. (1976) [1878] Anti-Duhring, Foreign Languages Press, Beijing.

Engels, F. (1987) [1845] The Condition of the Working Class in England, F. Wischnewetzky (trans.), Penguin Classics, London.

Engels, F. (2004) [1880] Socialism: Utopian and Scientific, International Publishers, New York, NY.

Etling, M. (2005) Our Lady of Fatima, Regina Press, Melville, NY.

Feather, V. (1963) The Essence of Trade Unionism, The Bodley Head, London.

Islam, M.A. and Deegan, C. (2008), 'Motivations for an organisation within a developing country to report social responsibility information: Evidence from Bangladesh', Accounting, Auditing \& Accountability Journal, Vol. 21, No. 6, pp.850-874.

James, K. and Leung, J.K.-S. (2017) Sydney's Construction Union Strategy and Immigrant Workers, second edition, Kieran James (via Lulu.com), Paisley, Scotland.

James, K., Murdoch, M. and Guo, X. (2018), 'Corporate social responsibility reporting in Scottish football: A Marxist analysis', Journal of Physical Fitness, Medicine \& Treatment in Sports, Vol. 2, No. 1, pp.1-15.

James, K. and Walsh, R. (2015), 'Bandung rocks, Cibinong shakes: Economics and applied ethics within the Indonesian death-metal community', Musicology Australia, Vol. 37, No. 1, pp.27-46.

James, K. and Walsh, R. (2017), 'The expropriation of goodwill and migrant labour in the transition to Australian football's A-League', International Journal of Sport Management and Marketing [published online].

James, K. and Walsh, R. (2018), 'Islamic religion and death metal music', Unpublished Working Paper, University of the West of Scotland and Notre-Dame University Sydney. 
John Paul II. (1991) On the Hundredth Anniversary of Rerum Novarum, Pauline Books \& Media, Boston, MA.

John Paul II. (n/d) [1987] Sollicitudo rei socialis [On Social Concern], Pauline Books \& Media, Boston, MA.

Leung, J.K.-S. and James, K. (2010a), 'From monocultural to multilingual: Strategic innovation in an Australian construction union', Korean Journal of Industrial Relations, Vol. 20, No. 1, pp.135-162.

Leung, J.K.-S., James, K., Mustata, R. and Bonaci, C. (2010b), 'Construction union strategy at the branch level in Sydney: A Roman Catholic perspective', International Journal of Social Economics, Vol. 37, No. 9, pp.488-511.

Leung, J.K.-S., James, K. and Sujan, A. (2011), 'From building site warriors to Korean church: Radical strategic realignment in Sydney's construction union', International Journal of Economics and Accounting, Vol. 3, No. 4, pp.387-416.

Marx, K.H. (1975) [1844] 'Economic and philosophical manuscripts', in: Early Writings, R. Livingstone and G. Benton (trans.), Penguin Classics, London, pp.279-400.

Marx, K.H. (1976) [1867] Capital - A Critique of Political Economy Volume 1, B. Fowkes (trans.), Penguin Classics, London.

Marx, K.H. (1981) [1894] Capital - A Critique of Political Economy Volume 3, D. Fernbach (trans.), Penguin Classics London.

Marx, K.H. (1994a) [1845] "Toward a critique of Hegel's philosophy of right": Introduction', in: L.H. Simon (Ed.): Selected Writings, Hackett Publishing Company, Indianapolis, IN, pp.27-39.

Marx, K.H. (1994b) [1859] 'Preface to "a contribution to the critique of political economy", in: L.H. Simon (Ed.): Selected Writings, Hackett Publishing Company, Indianapolis, IN, pp.209-213.

Marx, K.H. (1998) [1871] The Civil War in France, available online: http://www.marx2mao.com/M\&E/CWF71.html [accessed 14 April 2010].

Marx, K.H. and Engels, F. (1998) [1848] The Communist Manifesto, sesquicentennial edition, Signet Classics, New York, NY.

McKinstry, S. (2007), “Christie Malry's own double entry”, by B.S. Johnson: An interpretation as Foucauldian discourse', Critical Perspectives on Accounting, Vol. 18, No. 8, pp.975-991.

Mihret, D.G., James, K. and Mula, J.M. (2010), 'Antecedents and organizational performance implications of internal audit effectiveness: Some propositions and research agenda', Pacific Accounting Review, Vol. 22, No. 3, 2010, pp.224-252.

Mihret, D.G., James, K. and Mula, J.M. (2012a), 'Accounting professionalization amidst alternating state ideology in Ethiopia', Accounting, Auditing \& Accountability Journal, Vol. 25, No. 7, pp.1206-1233.

Mihret, D.G., Mula, J.M. and James, K. (2012b), 'The development of internal auditing in Ethiopia: The role of institutional norms', Journal of Financial Reporting and Accounting, Vol. 10, No. 2, pp.153-170.

Montefiore, S.S. (2005) Stalin: Court of the Red Tsar, Vintage Books, New York, NY.

Mosley, N. (1972) The Assassination of Trotsky, Michael Joseph, London.

O'Donovan, G. (2002), 'Environmental disclosures in the annual report: Extending the applicability and predictive power of legitimacy theory', Accounting, Auditing \& Accountability Journal, Vol. 15, No. 3, pp.344-371.

Ollman, B. (1976) Alienation: Marx's Conception of Man in Capitalist Society, $2^{\text {nd }}$ edition, Cambridge University Press, Cambridge.

Prasetyo, F.A. (2017), 'Punk and the city: A history of punk in Bandung', Punk \& Post-Punk, Vol. 6, No. 2, pp.189-211. 
Ratzinger, J. Cardinal and Bovone, A. (n/d) [1984] Instruction on Certain Aspects of the 'Theology of Liberation', St Paul Books \& Media, Boston, MA.

Reed, J. (1977) [1926] Ten Days that Shook the World, Penguin Classics, London.

Saefullah, H. (2017), “Nevermind the jahiliyyah, here's the hijrahs": Punk and the religious turn in the contemporary Indonesian underground scene', Punk \& Post-Punk, Vol. 6, No. 2, pp.263-289.

Sartre J-P. (2006) [1943] Being and Nothingness, Routledge Classics, London.

Steele, L. (2011) Broken Promises Never Die, Lachlan Steele (via Clydesdale Press), Paisley, Scotland.

Stourton, E. (2006) John Paul II Man of History, Hodder \& Stoughton, London.

Sy, A. and Tinker, T. (2011), 'From Melmott to Madoff: History in the (re) making', The Accounting Historians Journal, Vol. 38, No. 1, pp.141-158.

Taylor, A.J.P. (1977) [1964] 'Introduction to John Reed's Ten days that shook the world', in: Ten Days that Shook the World, Penguin Books, London, pp.vii-xix.

Tinker, T. (1999), 'Mickey Marxism rides again!' Critical Perspectives on Accounting, Vol. 10, No. 5, pp.643-670.

Tinker, T. (2002), 'Spectres of Marx and Braverman in the twilight of postmodernist labour process research', Work, Employment \& Society, Vol. 16, No. 2, pp.251-281.

Trotsky, L. (2004) [1937] The Revolution Betrayed, Dover Publications, New York, NY.

Trotsky, L. (2005) [1924] Literature and Revolution, Haymarket Books, Chicago, IL.

Wallach, J. (2008) Modern Noise, Fluid Genres: Popular Music in Indonesia, 1997-2001, University of Wisconsin Press, Madison, WI.

Wallach, J. (2011), "Unleashed in the east: Metal music, masculinity, and "Malayness" in Indonesia, Malaysia, and Singapore', in: J. Wallach, H.M. Berger and P.D. Greene (Eds.), Metal Rules the Globe: Heavy Metal Music around the World, Duke University Press, Durham, NC and London, Chapter 4, pp.86-105.

Žižek S. (2008) In Defence of Lost Causes, Verso, London and New York, NY. 